\title{
Pendugaan Daya Gabung dan Nilai Heterosis Hasil Persilangan Half Diallel Cabai Rawit (Capsicum annuum L.)
}

\section{Combining Ability and Heterosis Estimation in Half Diallel Crosses of Bird Pepper (Capsicum annuum L.)}

\author{
Oktaviana Shinta Risty ${ }^{2}$, Muhamad Syukur ${ }^{1,2^{*}}$ \\ ${ }^{1}$ Departemen Agronomi dan Hortikultura, Fakultas Pertanian IPB \\ Jl. Meranti Kampus IPB Darmaga, Bogor 16680, Indonesia \\ ${ }^{2}$ Pusat Kajian Hortikultura Tropika (PKH), Institut Pertanian Bogor \\ Kampus IPB Baranangsiang, Jalan Pajajaran Bogor 16143, Indonesia \\ *Penulis untuk korespondensi. email: muhsyukur@ipb.ac.id
}

Diterima 17 November 2016/Disetujui 9 Januari 2017

\begin{abstract}
The aim of this research was to study estimation general combining ability (GCA) and specific combining ability (SCA) of six bird pepper inbred lines (Capsicum annuum L.), heterosis and heterobeltiosis of fifteen bird pepper hybrids in half diallel crosses. The experiment were conducted from November 2013 to April 2014 using a Randomized Complete Block Design with three replications at Leuwikopo University Farm, IPB. Analysis of GCA and SCA were based on the Griffing's model of diallel design method II. Heterosis values were predicted based on the average values of their parents and heterobeltiosis were predicted based on the average values of the highest parents. Genotype IPB C174 had the highest GCA for fruit weight, fruit length, fruit width, and yield for each plant. Hybrid IPB C160x IPB C291 and IPB C291 x IPB C293 had positive SCA, heterosis, and heterobeltiosis values for some variable observed. Hybrid IPB C174x IPB C291 had better advantages than the commercial varieties which were Santika, Bhaskara, Sonar, and Nirmala on fruit weight characters.
\end{abstract}

Keywords: bird pepper, combining ability, half diallel, heterosis

\section{ABSTRAK}

Penelitian ini bertujuan untuk mempelajari pendugaan daya gabung umum (DGU) dan daya gabung khusus (DGK) enam galur murni cabai rawit (Capsicum annuum L.), heterosis dan heterobeltiosis 15 hibrida cabai rawit hasil persilangan half diallel. Penelitian dilaksanakan pada bulan November 2013 hingga April 2014 menggunakan Rancangan Kelompok Lengkap Teracak dengan tiga ulangan yang dilaksanakan di Kebun Percobaan Leuwikopo IPB. Nilai DGU dan DGK dianalisis berdasarkan metode II diallel model Griffing. Nilai heterosis dihitung berdasarkan nilai rata-rata kedua tetua dan heterobeltiosis dihitung berdasarkan nilai rata-rata tetua tertinggi. Genotipe IPB C174 mempunyai nilai DGU tertinggi untuk bobot per buah, panjang buah, diameter buah, dan bobot buah per tanaman. Hibrida IPB C160 x IPB C291 dan IPB C291 x IPB C293 memiliki nilai DGK, heterosis dan heterobeltiosis positif pada beberapa karakter yang diamati. Hibrida IPB C174 x IPB C291 memiliki keunggulan yang lebih baik dibandingkan varietas komersil Santika, Bhaskara, Sonar, dan Nirmala pada karakter bobot per buah.

Kata kunci: cabai rawit, daya gabung, half diallel, heterosis

\section{PENDAHULUAN}

Cabai (Capsicum annuum L.) merupakan komoditas penting yang hampir sebagian besar orang memerlukannya. Mulai dari pasar rakyat, pasar swalayan, warung pinggir jalan, restoran kecil, hotel berbintang, pabrik saus, bahkan pabrik mie instan sehari-harinya membutuhkan cabai dalam jumlah yang tidak sedikit (Prajnanta, 2007). Konsumsi ratarata cabai rawit di Indonesia pada tahun 2011 sebesar 1.21 kg kapita ${ }^{-1}$ tahun $^{-1}$, sedangkan di tahun 2012 mengalami peningkatan menjadi $1.40 \mathrm{~kg}$ kapita $^{-1}$ tahun $^{-1}$ (Kementan, 2013). Konsumsi rata-rata tersebut akan terus meningkat seiring bertambahnya jumlah penduduk dan berkembangnya industri sektor makanan di Indonesia.

Produksi cabai rawit di Indonesia pada tahun 2011 sebesar 594,227 ton dan mengalami peningkatan produksi di tahun 2012 sebesar 702,252 ton (BPS, 2013). Produktivitas cabai rawit di Indonesia sebesar 4.56 ton $\mathrm{ha}^{-1}$ di tahun 2010 dan 5.01 ton ha-1 di tahun 2011 (BPS dan Ditjen Horti, 2012). Indonesia masih melakukan impor cabai untuk memenuhi 
kebutuhan dalam negeri. Menurut Direktorat Jenderal Hortikultura (2013) Indonesia masih melakukan impor cabai sebanyak 22,737 ton pada tahun 2012. Direktorat Pengkajian Ekonomi (2012) menyatakan bahwa faktor penyebab rendahnya produktivitas di Indonesia adalah teknik budidaya yang konvensional, serangan hama dan penyakit tanaman, penanganan pascapanen kurang tepat, belum banyak digunakannya varietas berdaya hasil tinggi, dan kualitas benih rendah.

Peningkatan produksi cabai rawit harus dilakukan untuk memenuhi kebutuhan cabai nasional. Salah satu caranya dengan menggunakan benih bermutu dari varietas unggul yang dihasilkan oleh varietas hibrida. Varietas hibrida dapat dihasilkan melalui proses persilangan oleh tetua yang berbeda genotipnya. Menurut Sujiprihati et al. (2007), hibrida yang memiliki karakter unggul umumnya diperoleh dari hasil persilangan tetua-tetua yang memiliki daya gabung umum (DGU), daya gabung khusus (DGK), serta nilai heterosis dan atau heterobeltiosis yang tinggi. Tujuan dari penelitian ini adalah menduga nilai daya gabung umum dan daya gabung khusus enam galur murni cabai rawit, menduga nilai heterosis dan heterobeltiosis 15 hibrida cabai rawit hasil persilangan tetua secara setengah diallel (half diallel), dan menguji daya hasil 15 hibrida cabai rawit dibandingkan dengan empat varietas yang sudah komersial.

\section{METODE PENELITIAN}

Penanaman dilaksanakan di Kebun Percobaan Leuwikopo IPB Darmaga Bogor pada bulan November 2013 sampai bulan April 2014. Penelitian disusun menggunakan Rancangan Kelompok Lengkap Teracak faktor tunggal dengan tiga ulangan. Materi genetik yang digunakan adalah 25 genotipe cabai rawit (Capsicum annuum L.) yang terdiri atas 6 galur murni (IPB C10, IPB C145, IPB C160, IPB C174, IPB C291, dan IPB C293), 15 hibrida hasil persilangan half diallel, dan 4 varietas pembanding (Santika, Bhaskara, Sonar, dan Nirmala).

Lahan percobaan dibagi menjadi tiga ulangan. Masingmasing ulangan dibagi menjadi 25 bedeng dengan ukuran 5 $\mathrm{m} \times 1 \mathrm{~m}$ dan setiap bedengan ditutup dengan mulsa hitam perak. Bibit cabai ditanam satu bibit per lubang dengan jarak tanam $0.5 \mathrm{~m} \times 0.5 \mathrm{~m}$. Pemupukan dalan bentuk larutan NPK (16:16:16) $10 \mathrm{~g} \mathrm{~L}^{-1}$ dilakukan satu minggu sekali, dan masing-masing tanaman diberi $250 \mathrm{ml}$. Penyemprotan dilakukan seminggu sekali dengan menggunakan mankozeb $80 \%$ atau propineb $2 \mathrm{~g} \mathrm{~L}^{-1}$, insektisida prevonofos dengan konsentrasi $2 \mathrm{ml} \mathrm{L}^{-1}$. Pemanenan dilakukan setiap seminggu sekali selama 8 kali panen.

Karakter yang diamati adalah bobot per buah, panjang buah, diameter buah, bobot buah per tanaman dan jumlah buah per tanaman pada 10 tanaman contoh dari setiap satuan percobaan. Nilai daya gabung umum dan daya gabung khusus dianalisis menggunakan metode II Griffing yaitu berdasarkan persilangan half diallel. Pendugaan nilai heterosis dilihat berdasarkan nilai tengah kedua tetuanya sedangkan nilai heterobeltiosis dilihat dari nilai tengah tetua terbaik. Uji F dilakukan untuk mengetahui pengaruh genotipe terhadap keragaan tanaman. Apabila perlakuan berpengaruh nyata antara genotipe maka akan dilakukan uji lanjut dengan metode uji t-Dunnett pada taraf 5\% untuk membandingkan hibrida (F1) dengan varietas pembanding yang telah komersil dan uji duncan's multiple range test (DMRT) untuk mengetahui hibrida (F1) terbaik.

\section{HASIL DAN PEMBAHASAN}

\section{Daya Gabung}

Daya gabung ada dua macam yaitu daya gabung umum dan daya gabung khusus. Daya gabung umum (DGU) dapat diartikan sebagai ukuran penampilan ratarata tetua itu. Daya gabung khusus (DGK) merupakan kemampuan suatu kombinasi tetua untuk menunjukkan penampilan keturunan (Syukur et al., 2015). Analisis ragam pada Tabel 1 menunjukkan bahwa genotipe-genotipe yang diuji berpengaruh nyata untuk semua karakter yang diamati, sehingga analisis ragam untuk daya gabung dapat dilakukan. Daya gabung umum (DGU) menunjukkan pengaruh yang nyata pada karakter bobot per buah, panjang buah, dan diameter buah, sedangkan daya gabung khusus (DGK) berpengaruh nyata untuk karakter panjang buah, jumlah buah per tanaman dan bobot buah per tanaman. Hafsah et al. (2007) menyatakan bahwa nilai daya gabung umum (DGU) dan daya gabung khusus (DGK) yang nyata mengindikasikan adanya gen aditif dan dominan pada karakter yang diamati.

Nilai keragaman genetik pada karakter bobot per buah, panjang buah, dan diameter buah memiliki nilai ragam aditif yang lebih besar dari ragam dominan, kecuali pada karakter jumlah buah per tanaman dan bobot buah per tanaman yang menunjukkan nilai ragam dominan lebih besar dari ragam aditif (Tabel 1). Menurut Sitaresmi et al. (2010), nilai ragam aditif yang lebih besar dibandingkan ragam dominan pada karakter yang diamati mengindikasikan adanya aksi gen aditif lebih banyak daripada aksi gen dominan.

Tetua IPB C174 memiliki nilai DGU tertinggi untuk semua karakter yang diamati yaitu bobot per buah, panjang buah, diameter buah, dan bobot buah per tanaman. Nilai daya gabung umum tertinggi untuk karakter jumlah buah per tanaman dimiliki genotipe IPB C293 (Tabel 2). Menurut Syukur et al. (2015) suatu tetua yang memiliki daya gabung umum tinggi mengindikasikan bahwa tetua tersebut memiliki kemampuan berkombinasi yang baik dengan tetua lain dalam menghasilkan hibrida.

Hibrida IPB C160 x IPB C291 memiliki nilai DGK tertinggi pada karakter bobot per buah, panjang buah, dan bobot buah per tanaman. Nilai DGK tertinggi untuk karakter diameter buah dihasilkan dari persilangan IPB C291 x IPB C293, dan nilai daya gabung umum tertinggi untuk karakter jumlah buah per tanaman dimiliki genotipe IPB C174 x IPB C291 (Tabel 2). Nilai DGK yang tinggi dan positif tidak hanya berasal dari tetua dengan DGU yang tinggi. Persilangan antara tetua yang memiliki DGU positif dengan tetua yang memiliki DGU negatif umumnya menghasilkan 
Comm. Hort. J, Februari 2017, 1(1):34-41

Tabel 1. Analisis ragam hasil persilangan half diallel enam genotipe cabai rawit

\begin{tabular}{lcccccc}
\hline \multirow{2}{*}{ Sumber keragaman } & $\mathrm{db}$ & \multicolumn{3}{c}{ Kuadrat tengah } \\
\cline { 3 - 7 } & & $\mathrm{BpB}$ & $\mathrm{PB}$ & $\mathrm{DB}$ & $\mathrm{JBpT}$ & $\mathrm{BBpT}$ \\
\hline Genotipe & 20 & $1.03^{* *}$ & $1.57^{* *}$ & $1.30^{*}$ & $11925.67^{* *}$ & $5749.73^{*}$ \\
DGU & 5 & $1.27^{* *}$ & $1.74^{* *}$ & $1.49^{* *}$ & $4517.50 \mathrm{tn}$ & $662.37 \mathrm{tn}$ \\
DGK & 15 & $0.03 \mathrm{tn}$ & $0.12^{* *}$ & $0.08 \mathrm{tn}$ & $3794.46^{* *}$ & $2334.64^{* *}$ \\
Galat & 40 & 0.06 & 0.13 & 0.37 & 3270.19 & 1768.87 \\
Ragam aditif & & 0.31 & 0.41 & 0.35 & 180.76 & -418.07 \\
Ragam dominan & & 0.02 & 0.07 & -0.04 & 2704.40 & 1745.02 \\
KK(\%) & 11.26 & 7.41 & 6.71 & 27.07 & 23.30 \\
\hline
\end{tabular}

Keterangan: BpB: bobot per buah, PB: panjang buah, DB: diameter buah, JBpT: jumlah buah per tanaman, BBpT: bobot buah per tanaman; $*$ : berpengaruh nyata pada taraf $5 \%, * *$ : berpengaruh nyata pada taraf $1 \%$, tn: tidak berpengaruh nyata

Tabel 2. Daya gabung umum (DGU) dan daya gabung khusus (DGK)

\begin{tabular}{|c|c|c|c|c|c|}
\hline \multirow{2}{*}{ Genotipe (IPB C-) } & \multicolumn{5}{|c|}{ Karakter hasil } \\
\hline & $\mathrm{BpB}$ & $\mathrm{PB}$ & DB & $\mathrm{JBpT}$ & $\mathrm{BBpT}$ \\
\hline \multicolumn{6}{|l|}{ DGU } \\
\hline 10 & -0.23 & -0.35 & -0.35 & -10.57 & -6.04 \\
\hline 145 & -0.31 & -0.36 & -0.42 & -16.24 & -7.25 \\
\hline 160 & -0.29 & -0.37 & -0.34 & -14.71 & -9.29 \\
\hline 174 & 0.74 & 0.77 & 0.57 & -18.78 & 13.83 \\
\hline 291 & 0.11 & 0.32 & 0.42 & 24.60 & 2.26 \\
\hline 293 & -0.03 & -0.01 & 0.12 & 35.69 & 6.50 \\
\hline \multicolumn{6}{|l|}{ DGK } \\
\hline $10 \times 145$ & -0.04 & 0.03 & 0.16 & -1.08 & -9.63 \\
\hline $10 \times 160$ & 0.18 & 0.50 & 0.26 & -40.62 & -15.51 \\
\hline $10 \times 174$ & 0.00 & -0.41 & 0.41 & 42.70 & 47.73 \\
\hline $10 \times 291$ & 0.02 & 0.14 & -0.41 & -64.18 & -31.71 \\
\hline $10 \times 293$ & 0.16 & 0.24 & 0.35 & 77.23 & 55.00 \\
\hline $145 \times 160$ & -0.07 & -0.26 & -0.13 & 26.32 & -17.63 \\
\hline $145 \times 174$ & -0.04 & 0.35 & -0.29 & 43.88 & 56.09 \\
\hline 145 x 291 & 0.12 & 0.22 & -0.07 & 8.51 & 24.81 \\
\hline $145 \times 293$ & 0.12 & 0.29 & 0.04 & -8.33 & 33.67 \\
\hline $160 \times 174$ & -0.18 & -0.16 & 0.15 & 0.10 & 34.94 \\
\hline $160 \times 291$ & 0.27 & 0.56 & 0.06 & 35.23 & 69.90 \\
\hline $160 \times 293$ & -0.04 & -0.20 & -0.10 & -22.12 & -8.69 \\
\hline 174 x 291 & 0.12 & 0.06 & -0.13 & 129.29 & 26.95 \\
\hline $174 \times 293$ & 0.09 & -0.10 & -0.10 & 38.45 & 2.23 \\
\hline $291 \times 293$ & 0.21 & 0.08 & 0.48 & -37.18 & 18.21 \\
\hline
\end{tabular}

Keterangan: BpB: bobot per buah, PB: panjang buah, DB: diameter buah, JBpT: jumlah buah per tanaman, BBpT: bobot buah per tanaman

DGK tinggi dan positif. Fenomena yang serupa ditunjukkan dalam penelitian cabai spesies Capsicum annuum L. oleh Daryanto et al. (2010) serta Tembhurne dan Rao (2012). Genotipe-genotipe yang mempunyai DGU positif dengan
DGU negatif umumnya memberikan efek DGK yang tinggi karena gen-gen yang menguntungkan dapat menutupi gengen yang merugikan dan mampu bergabung dengan baik (Iriany et al. 2011). 


\section{Heterosis dan Heterobeltiosis}

Hasil persilangan dengan nilai heterosis dan heterobeltiosis positif diharapkan untuk karakter daya hasil. Jika suatu keturunan mengalami penurunan karakter yang diinginkan, maka heterosisnya bernilai negatif.

Kombinasi persilangan yang secara nyata mendapatkan rataaan bobot per buah tertinggi diantara kombinasi persilangan lainnya adalah IPB C174 x IPB C291 (3.06 g), akan tetapi hibrida ini memiliki nilai heterobeltiosis negatif. Nilai heterobeltiosis yang negatif menunjukkan nilai rataan hibridanya tidak lebih tinggi dari nilai tetua terbaik. Terdapat empat hibrida yang memiliki nilai heterosis dan heterobeltiosis tinggi yaitu hibrida IPB C160 x IPB C291, IPB C291 x IPB C293, IPB C10 x IPB C293, dan IPB C10 $x$ IPB C160. Nilai heterosis paling tinggi dimiliki IPB C160 x IPB C291 yaitu 28.78\% sedangkan IPB C291 x IPB C293 memiliki nilai heterobeltiosis tertinggi yaitu $22.68 \%$ (Tabel 3).

Nilai rataan tetua pada karakter panjang buah adalah 3.86-6.57 cm dan rataan hibridanya adalah 3.90-6.04 cm. Hasil persilangan IPB C174 x IPB C291 memiliki panjang buah $(6.04 \mathrm{~cm})$ nyata lebih besar dibandingkan hasil persilangan lainnya. Kisaran nilai heterosis adalah $-6.76 \%$ hingga $20.81 \%$ dan nilai heterobeltiosisnya adalah -25.42 $\%$ hingga $18.44 \%$. Terdapat tujuh kombinasi persilangan yang memiliki nilai heterosis dan heterobeltiosis positif. Nilai heterosis dan heterobeltiosis positif menunjukkan kombinasi persilangan memiliki nilai lebih baik dari rataan kedua tetua dan rataan tetua terbaik. Nilai heterosis terbesar dimiliki hibrida IPB C160 x IPB C291, sedangkan hibrida
IPB C10 x IPB C160 memiliki nilai heterobeltiosis terbesar (Tabel 4).

Nilai rata-rata diameter buah enam tetua genotipe cabai berkisar antara $8.02-10.23 \mathrm{~mm}$, sedangkan nilai rata-rata hibridanya berkisar $8.22-10.13 \mathrm{~mm}$. Hibrida yang memiliki nilai diameter buah terbesar dimiliki IPB C291 x IPB C293 dengan nilai heterosis dan heterobeltiosis yang positif. Terdapat empat hibrida yang memiliki nilai heterosis dan heterobeltiosis positif yaitu IPB C10 x IPB C145, IPB C10 x IPB C160, IPB C10 x IPB C293, dan IPB C291 x IPB C293. Kombinasi persilangan IPB C10 x IPB C293 memiliki nilai heterosis paling tinggi yaitu $8.40 \%$ dan nilai heterobeltiosis tertinggi dimiliki kombinasi persilangan IPB C10 x IPB C160. Menurut Herison et al. (2001) nilai heterobeltiosis merupakan indikator diperolehnya hibrida berdaya hasil tinggi dari tetuanya (Tabel 5).

Jumlah buah per tanaman tetua memiliki kisaran nilai 46.38-258.50 dan hibridanya memiliki kisaran nilai 145.25-346.25. IPB C174 x IPB C291 merupakan hibrida dengan jumlah buah per tanaman terbanyak dibandingkan hibrida lain yang diuji (Tabel 6). Nilai duga heterosis heterosis berkisar $-20.98-155.65 \%$. Terdapat sebelas hibrida yang memiliki nilai duga heterosis positif. Nilai heterosis terbaik dimiliki oleh IPB C174 x IPB C291. Pendugaan nilai heterobeltiosis berada pada kisaran -28.29$54.23 \%$. Sembilan kombinasi persilangan memiliki nilai heterobeltiosis positif. Hibrida IPB C174 x IPB C291 juga memiliki nilai duga heterobeltiosis terbaik dibandingkan hibrida lain yang diuji.

Rataan bobot buah per tanaman tetua berkisar 122.36$145.49 \mathrm{~g}$ dan nilai rataan hibridanya berkisar 145.03-243.39

Tabel 3. Nilai rata-rata bobot per buah P1, P2, dan F1 serta nilai heterosis dan heterobeltiosis

\begin{tabular}{|c|c|c|c|c|c|}
\hline \multirow{2}{*}{ Genotipe (IPB C-) } & \multicolumn{3}{|c|}{ Bobot per buah $(\mathrm{g})$} & \multirow{2}{*}{ Heterosis $(\%)$} & \multirow{2}{*}{ Heterobeltiosis $(\%)$} \\
\hline & $\mathrm{P} 1$ & $\mathrm{P} 2$ & F1 & & \\
\hline $10 \times 145$ & 1.47 & 1.42 & $1.51 \mathrm{fg}$ & 4.50 & 2.72 \\
\hline $10 \times 160$ & 1.47 & 1.43 & $1.75 \mathrm{efg}$ & 20.69 & 19.05 \\
\hline $10 \times 174$ & 1.47 & 3.57 & $2.60 \mathrm{bc}$ & 3.17 & -27.17 \\
\hline $10 \times 291$ & 1.47 & 1.94 & $1.99 \mathrm{de}$ & 16.72 & 2.58 \\
\hline $10 \times 293$ & 1.47 & 1.76 & $1.99 \mathrm{de}$ & 23.22 & 13.07 \\
\hline $145 \times 160$ & 1.42 & 1.43 & $1.41 \mathrm{~g}$ & -1.05 & -1.40 \\
\hline $145 \times 174$ & 1.42 & 3.57 & $2.48 \mathrm{bc}$ & -0.60 & -30.53 \\
\hline $145 \times 291$ & 1.42 & 1.94 & $2.01 \mathrm{de}$ & 19.64 & 3.61 \\
\hline $145 \times 293$ & 1.42 & 1.76 & $1.87 \mathrm{ef}$ & 17.61 & 6.25 \\
\hline $160 \times 174$ & 1.43 & 3.57 & $2.36 \mathrm{~cd}$ & -5.60 & -33.89 \\
\hline $160 \times 291$ & 1.43 & 1.94 & $2.17 \mathrm{cde}$ & 28.78 & 11.86 \\
\hline $160 \times 293$ & 1.43 & 1.76 & $1.73 \mathrm{efg}$ & 8.46 & -1.70 \\
\hline 174 x 291 & 3.57 & 1.94 & $3.06 \mathrm{a}$ & 11.07 & -14.29 \\
\hline $174 \times 293$ & 3.57 & 1.76 & $2.88 \mathrm{ab}$ & 8.07 & -19.33 \\
\hline $291 \times 293$ & 1.94 & 1.76 & $2.38 \mathrm{~cd}$ & 28.65 & 22.68 \\
\hline
\end{tabular}

Keterangan: P1: tetua betina, P2: tetua jantan; F1: generasi pertama; Angka diikuti huruf sama pada kolom yang sama tidak berbeda nyata berdasarkan DMRT pada taraf 5\% 
Comm. Hort. J, Februari 2017, 1(1):34-41

Tabel 4. Nilai rata-rata panjang buah $\mathrm{P} 1, \mathrm{P} 2$, dan F1 serta nilai heterosis dan heterobeltiosis

\begin{tabular}{lcccrr}
\hline \multirow{2}{*}{ Genotipe (IPB C-) } & \multicolumn{3}{c}{ Panjang buah $(\mathrm{cm})$} & Heterosis (\%) & Heterobeltiosis (\%) \\
\cline { 2 - 5 } $10 \times 145$ & P1 & P2 & F1 & 7.95 & 6.85 \\
$10 \times 160$ & 3.94 & 3.86 & $4.21 \mathrm{gh}$ & 18.59 & 18.44 \\
$10 \times 174$ & 3.94 & $4.67 \mathrm{efg}$ & -6.76 & -25.42 \\
$10 \times 291$ & 3.94 & 6.57 & $4.90 \mathrm{c}-\mathrm{f}$ & 11.81 & -0.13 \\
$10 \times 293$ & 3.94 & 5.01 & $5.00 \mathrm{~b}-\mathrm{e}$ & 10.08 & 0.99 \\
$145 \times 160$ & 3.94 & 4.72 & $4.77 \mathrm{~d}-\mathrm{g}$ & 0.13 & -0.76 \\
$145 \times 174$ & 3.86 & 3.93 & $3.90 \mathrm{~h}$ & 8.28 & -14.05 \\
$145 \times 291$ & 3.86 & 6.57 & $5.65 \mathrm{ab}$ & 14.32 & 1.20 \\
$145 \times 293$ & 3.86 & 5.01 & $5.07 \mathrm{~b}-\mathrm{e}$ & 12.04 & 1.84 \\
$160 \times 174$ & 3.86 & 4.72 & $4.81 \mathrm{~d}-\mathrm{g}$ & -2.29 & -21.92 \\
$160 \times 291$ & 3.93 & 6.57 & $5.13 \mathrm{~b}-\mathrm{e}$ & 20.81 & 7.78 \\
$160 \times 293$ & 3.93 & 5.01 & $5.40 \mathrm{a}-\mathrm{d}$ & -0.27 & -8.62 \\
$174 \times 291$ & 3.93 & 4.72 & $4.31 \mathrm{fgh}$ & 4.32 & -8.07 \\
$174 \times 293$ & 6.57 & 5.01 & $6.04 \mathrm{a}$ & -1.68 & -15.53 \\
$291 \times 293$ & 6.57 & 4.72 & $5.55 \mathrm{abc}$ & 5.53 & 5.39 \\
\hline
\end{tabular}

Keterangan: P1: tetua betina, P2: tetua jantan; F1: generasi pertama; Angka diikuti huruf sama pada kolom yang sama tidak berbeda nyata berdasarkan DMRT pada taraf 5\%

Tabel 5. Nilai rata-rata diameter buah $\mathrm{P} 1, \mathrm{P} 2$, dan F1 serta nilai heterosis dan heterobeltiosis

\begin{tabular}{lccccc}
\hline \multirow{2}{*}{ Genotipe (IPB C-) } & \multicolumn{3}{c}{ Diameter buah $(\mathrm{mm})$} & Heterosis (\%) & Heterobeltiosis (\%) \\
\cline { 2 - 5 } $10 \times 145$ & P1 & P2 & F1 & 3.35 & 0.95 \\
$10 \times 160$ & 8.02 & 8.41 & $8.49 \mathrm{de}$ & 6.24 & 4.33 \\
$10 \times 174$ & 8.02 & 10.23 & $9.74 \mathrm{abc}$ & 6.74 & -4.79 \\
$10 \times 291$ & 8.02 & 9.98 & $8.76 \mathrm{cde}$ & -2.67 & -12.22 \\
$10 \times 293$ & 8.02 & 9.01 & $9.23 \mathrm{a}-\mathrm{e}$ & 8.4 & 2.44 \\
$145 \times 160$ & 8.02 & 8.32 & $8.22 \mathrm{e}$ & -1.73 & -2.26 \\
$145 \times 174$ & 8.41 & 10.23 & $8.96 \mathrm{~b}-\mathrm{e}$ & -3.86 & -12.41 \\
$145 \times 291$ & 8.41 & 9.98 & $9.04 \mathrm{a}-\mathrm{e}$ & -1.69 & -9.42 \\
$145 \times 293$ & 8.41 & 9.01 & $8.84 \mathrm{~b}-\mathrm{e}$ & 1.49 & -1.89 \\
$160 \times 174$ & 8.41 & 10.23 & $9.49 \mathrm{a}-\mathrm{d}$ & 2.32 & -7.23 \\
$160 \times 291$ & 8.32 & 9.98 & $9.25 \mathrm{a}-\mathrm{e}$ & 1.09 & -7.31 \\
$160 \times 293$ & 8.32 & 9.01 & $8.79 \mathrm{cde}$ & 1.44 & -2.44 \\
$174 \times 291$ & 8.32 & 9.98 & $9.97 \mathrm{ab}$ & -1.34 & -2.54 \\
$174 \times 293$ & 10.23 & 9.01 & $9.70 \mathrm{abc}$ & 0.83 & -5.18 \\
$291 \times 293$ & 10.23 & 9.01 & $10.13 \mathrm{a}$ & 6.69 & 1.5 \\
\hline
\end{tabular}

Keterangan: P1: tetua betina, P2: tetua jantan; F1: generasi pertama; Angka diikuti huruf sama pada kolom yang sama tidak berbeda nyata berdasarkan DMRT pada taraf $5 \%$

g. Semua hibrida memiliki bobot buah per tanaman lebih besar daripada nilai rataan kedua tetuanya dan nilai tetua terbaik, hal tersebut ditunjukkan dengan nilai heterosis dan heterobeltiosis positif kecuali pada hibrida IPB C10 x IPB C291. 
Comm. Hort. J, Februari 2017, 1(1):34-41

Tabel 6. Nilai rata-rata jumlah buah per tanaman P1, P2, dan F1 serta nilai heterosis dan heterobeltiosis

\begin{tabular}{lccccc}
\hline \multirow{2}{*}{ Genotipe (IPB C-) } & \multicolumn{3}{c}{ Jumlah buah per tanaman } & Heterosis (\%) & Heterobeltiosis(\%) \\
\cline { 2 - 5 } $10 \times 145$ & P1 & P2 & F1 & 12.08 & 0.14 \\
$10 \times 160$ & 183.00 & 144.00 & $183.25 \mathrm{c}$ & -20.47 & -20.63 \\
$10 \times 174$ & 183.00 & 182.25 & $145.25 \mathrm{c}$ & 95.75 & 22.68 \\
$10 \times 291$ & 183.00 & 46.38 & $224.50 \mathrm{bc}$ & -20.98 & -28.29 \\
$10 \times 293$ & 183.00 & 224.50 & $161.00 \mathrm{c}$ & 42.02 & 21.28 \\
$145 \times 160$ & 183.00 & 258.50 & $313.50 \mathrm{ab}$ & 26.59 & 13.31 \\
$145 \times 174$ & 144.00 & 182.25 & $206.50 \mathrm{bc}$ & 131.12 & 52.78 \\
$145 \times 291$ & 144.00 & 46.38 & $220.00 \mathrm{bc}$ & 23.74 & 1.56 \\
$145 \times 293$ & 144.00 & 224.50 & $228.00 \mathrm{bc}$ & 10.43 & -14.02 \\
$160 \times 174$ & 144.00 & 258.50 & $222.25 \mathrm{bc}$ & 55.49 & -2.47 \\
$160 \times 291$ & 182.25 & 46.38 & $177.75 \mathrm{c}$ & 26.00 & 14.14 \\
$160 \times 293$ & 182.25 & 224.50 & $256.25 \mathrm{abc}$ & -4.71 & -18.76 \\
$174 \times 291$ & 182.25 & 258.50 & $210.00 \mathrm{bc}$ & 155.65 & 54.23 \\
$174 \times 293$ & 46.38 & 224.50 & $346.25 \mathrm{a}$ & 74.82 & 3.09 \\
$291 \times 293$ & 46.38 & 258.50 & $266.50 \mathrm{abc}$ & -3.00 & -9.38 \\
\hline
\end{tabular}

Keterangan: P1: tetua betina, P2: tetua jantan; F1: generasi pertama; Angka diikuti huruf sama pada kolom yang sama tidak berbeda nyata berdasarkan DMRT pada taraf 5\%

Hibrida IPB C145 x IPB C174 dan IPB C160 x IPB C291 memiliki nilai tertinggi yang nyata untuk karakter bobot buah per tanaman. Heterosis dan heterobeltiosis tertinggi untuk karakter bobot buah per tanaman dimiliki oleh genotipe IPB C145 x IPB C174. Menurut Iriany et al. (2011) nilai heterosis dan heterobeltiosis yang tinggi untuk karakter yang diamati disebabkan tetua yang digunakan dalam persilangan memiliki jarak genetik yang jauh (Tabel 7).

Tabel 7. Nilai rata-rata bobot buah per tanaman P1, P2, dan F1 serta nilai heterosis dan heterobeltiosis

\begin{tabular}{|c|c|c|c|c|c|}
\hline \multirow{2}{*}{ Genotipe (IPB C-) } & \multicolumn{3}{|c|}{ Bobot buah per tanaman (g) } & \multirow{2}{*}{ Heterosis $(\%)$} & \multirow{2}{*}{ Heterobeltiosis $(\%)$} \\
\hline & P1 & P2 & F1 & & \\
\hline $10 \times 145$ & 145.49 & 122.36 & $157.59 b c$ & 17.67 & 8.32 \\
\hline $10 \times 160$ & 145.49 & 130.42 & $149.67 \mathrm{c}$ & 8.49 & 2.87 \\
\hline $10 \times 174$ & 145.49 & 124.19 & $236.03 \mathrm{ab}$ & 75.04 & 62.23 \\
\hline $10 \times 291$ & 145.49 & 130.95 & $145.03 \mathrm{c}$ & 4.93 & -0.32 \\
\hline $10 \times 293$ & 145.49 & 143.31 & $235.98 \mathrm{ab}$ & 63.42 & 62.20 \\
\hline $145 \times 160$ & 122.36 & 130.42 & $146.34 \mathrm{c}$ & 15.79 & 12.21 \\
\hline $145 \times 174$ & 122.36 & 124.19 & $243.18 \mathrm{a}$ & 97.27 & 95.82 \\
\hline $145 \times 291$ & 122.36 & 130.95 & $200.34 a b c$ & 58.18 & 52.99 \\
\hline $145 \times 293$ & 122.36 & 143.31 & $213.44 a b c$ & 60.68 & 48.94 \\
\hline $160 \times 174$ & 130.42 & 124.19 & $220.00 \mathrm{abc}$ & 72.81 & 68.68 \\
\hline $160 \times 291$ & 130.42 & 130.95 & $243.39 \mathrm{a}$ & 86.24 & 85.87 \\
\hline $160 \times 293$ & 130.42 & 143.31 & $169.04 \mathrm{abc}$ & 23.51 & 17.96 \\
\hline $174 \times 291$ & 124.19 & 130.95 & $223.56 a b c$ & 75.24 & 70.72 \\
\hline $174 \times 293$ & 124.19 & 143.31 & 203.07abc & 51.83 & 41.70 \\
\hline $291 \times 293$ & 130.95 & 143.31 & $207.49 \mathrm{abc}$ & 51.31 & 44.79 \\
\hline
\end{tabular}

Keterangan: P1: tetua betina, P2: tetua jantan; F1: generasi pertama; Angka diikuti huruf sama pada kolom yang sama tidak berbeda nyata berdasarkan DMRT pada taraf 5\% 
Daya Hasil

Tabel 8 menunjukkan hibrida IPB C174 x IPB C291 memiliki bobot per buah yang berbeda nyata dengan keempat varietas pembanding. Hibrida IPB C10 x IPB C174, IPB C145 x IPB C174, C174, dan IPB C174 x IPB C293 memiliki bobot per buah yang berbeda nyata dengan varietas Santika, Sonar, dan Nirmala. Genotipe IPB C160 x IPB C174, IPB C160 x IPB C291, dan IPB C291 x IPB C293 memiliki bobot per buah yang lebih besar dibandingkan varietas Santika dan Nirmala. IPB C10 x IPB C174, IPB C10 x IPB C291, IPB C145 x IPB C291, dan IPB C160 x IPB C174 memiliki panjang buah yang nyata lebih besar dibandingkan varietas Santika dan Nirmala. Panjang buah genotipe IPB C145 x IPB C174, IPB C160 x IPB C291, IPB 174 x IPB C291, IPB C174 x IPB C293, dan IPB C291 x IPB C293 nyata lebih besar dibandingkan varietas Santika, Sonar, dan Nirmala. Karakter diameter buah yang berbeda nyata lebih besar dibandingkan varietas pembanding Nirmala adalah genotipe IPB C174 x IPB C291 dan IPB C291 x IPB C293.

Genotipe IPB C10 x IPB C293 dan IPB C174 x IPB C291 memiliki jumlah buah per tanaman berbeda nyata dengan varietas pembanding Sonar. Bobot buah per tanaman nyata lebih besar daripada varietas pembanding Sonar dan Nirmala dimiliki IPB C10 x IPB C174, IPB C10 x IPB C293, IPB C145 x IPB C174, dan IPB C160 x IPB C291 (Tabel 8).

Tabel 8. Nilai rata-rata keragaman hasil persilangan half diallel enam genotipe cabai rawit dan empat varietas pembanding

\begin{tabular}{|c|c|c|c|c|c|}
\hline \multirow{2}{*}{ Genotipe (IPB C-) } & \multicolumn{5}{|c|}{ Karakter hasil } \\
\hline & $\mathrm{BpB}$ & PB & DB & JBpT & $\mathrm{BBpT}$ \\
\hline $10 \times 145$ & $1.51 \mathrm{~b}$ & $4.21 b$ & 8.49 & 104.18 & 157.59 \\
\hline $10 \times 160$ & $1.75 b$ & $4.67 \mathrm{ab}$ & 8.68 & 86.82 & 149.67 \\
\hline $10 \times 174$ & $2.60 \mathrm{acd}$ & 4.90ad & 9.74 & 90.15 & $236.03 \mathrm{~cd}$ \\
\hline $10 \times 291$ & 1.99 & $5.00 \mathrm{ad}$ & 8.76 & 73.19 & 145.03 \\
\hline $10 \times 293$ & 1.99 & $4.77 \mathrm{ab}$ & 9.23 & $117.49 \mathrm{c}$ & $235.98 \mathrm{~cd}$ \\
\hline $145 \times 160$ & $1.41 \mathrm{~b}$ & $3.90 \mathrm{~b}$ & $8.22 b$ & 103.90 & 146.34 \\
\hline $145 \times 174$ & $2.48 \mathrm{acd}$ & $5.65 \mathrm{acd}$ & 8.96 & 97.93 & $243.18 \mathrm{~cd}$ \\
\hline $145 \times 291$ & 2.01 & $5.07 \mathrm{ad}$ & 9.04 & 101.45 & 200.34 \\
\hline $145 \times 293$ & 1.87 & $4.81 \mathrm{a}$ & 8.84 & 114.05 & 213.44 \\
\hline $160 \times 174$ & $2.36 \mathrm{ad}$ & $5.13 \mathrm{ad}$ & 9.49 & 93.35 & 220.00 \\
\hline $160 \times 291$ & $2.17 \mathrm{ad}$ & $5.40 \mathrm{acd}$ & 9.25 & 116.75 & $243.39 \mathrm{~cd}$ \\
\hline $160 \times 293$ & $1.73 b$ & $4.31 b$ & 8.79 & 97.09 & 169.04 \\
\hline $174 \times 291$ & $3.06 \mathrm{a}-\mathrm{d}$ & $6.04 \mathrm{acd}$ & $9.97 \mathrm{~d}$ & $74.61 \mathrm{c}$ & 223.56 \\
\hline $174 \times 293$ & $2.88 \mathrm{acd}$ & $5.55 \mathrm{acd}$ & 9.70 & 70.73 & 203.07 \\
\hline $291 \times 293$ & $2.38 \mathrm{ad}$ & $5.28 \mathrm{acd}$ & $10.13 d$ & 87.53 & 207.49 \\
\hline Santika & 1.56 & 3.79 & 8.94 & 106.15 & 165.30 \\
\hline Bhaskara & 2.37 & 5.59 & 9.82 & 94.02 & 223.36 \\
\hline Sonar & 1.85 & 4.36 & 9.00 & 69.71 & 128.92 \\
\hline Nirmala & 1.5 & 4.09 & 8.41 & 85.03 & 129.49 \\
\hline
\end{tabular}

Keterangan: BpB: bobot per buah (g), PB: panjang buah (cm), DB: diameter buah (mm), JBpT: Jumlah Buah per Tanaman, BBpT: bobot buah per tanaman $(\mathrm{g})$; Angka yang diikuti oleh huruf a, b, c, d pada kolom yang sama berturut-turut berbeda nyata dengan Santika, Bhaskara, Sonar, dan Nirmala berdasarkan uji Dunnett taraf 5\%

\section{KESIMPULAN}

Genotipe IPB C174 adalah tetua yang memiliki nilai daya gabung umum terbaik untuk karakter bobot per buah, panjang buah, diameter buah, dan bobot buah per tanaman, sedangkan genotipe yang memiliki DGU tertinggi pada karakter jumlah buah per tanaman adalah IPB C293. Genotipe IPB C160 x IPB C291 memiliki nilai daya gabung khusus terbaik untuk karakter bobot per buah, panjang buah, dan bobot buah per tanaman. IPB C291 x IPB C293 merupakan hibrida yang memiliki nilai DGK terbaik untuk diameter buah. Nilai DGK terbaik pada karakter jumlah buah per tanaman dimiliki genotipe IPB C174 x IPB C291.

Terdapatperbedaantingkatheterosis danheterobeltiosis diantara 15 hibrida yang diuji. Hibrida IPB C160 x IPB C291 dan IPB C291 x IPB C293 merupakan hibrida yang memiliki nilai heterosis dan heterobeltiosis yang baik pada karakter yang diamati.

Genotipe IPB C174 x IPB C291 memiliki karakter bobot per buah lebih baik dari keempat varietas pembanding, 
dan memiliki jumlah buah per tanaman yang lebih banyak dibandingkan varietas Sonar. IPB C145 x IPB C174 memiliki keunggulan yang lebih baik dari varietas pembanding Sonar dan Nirmala pada karakter bobot per buah, panjang buah, dan bobot buah per tanaman.

\section{UCAPAN TERIMA KASIH}

Terima kasih disampaikan kepada kementerian Ristek melalui hibah SINAS tahun 2014 atas nama Prof. Dr. Sobir (Pusat Kajian Hortikultura Tropika (PKHT)) Institut Pertanian Bogor.

\section{DAFTAR PUSTAKA}

[BPS] Badan Pusat Statistik. 2013. Berita Resmi Statistik. http:www.bps.go.idbrs_filehorti_01agu13.pdf. [20 September 2013].

[BPS dan Ditjen Horti] Badan Pusat Statistik dan Direktorat Jenderal Hortikultura. 2012. Produktivitas cabe rawit menurut provinsi, 2007 - 2011. http://www. deptan.go.id/infoeksekutif/horti/pdf-ATAP2011/ ProdvCabeRawit.pdf. [26 November 2013].

Daryanto, A., S. Sujiprihati, M. Syukur. 2010. Heterosis dan daya gabung karakter agronomi cabai (Capsicum annuum L.) hasil persilangan half diallel. J. Agron. Indonesia 38(2):113-121.

[Kementan] Kementerian Pertanian. 2013. Konsumsi ratarata per kapita setahun beberapa bahan makanan di Indonesia, 2008-2012. http://www.deptan.go.id/ Indikator/tabe-15b-konsumsi-rata.pdf. [20 September 2013].

Direktorat Pengkajian Ekonomi. 2013. Meningkatkan produktivitas pertanian guna mewujudkan ketahanan pangan dalam rangka ketahanan nasional. Jurnal Kajian Lemhannas RI 15:12-19.
[Ditjen Horti] Direktorat Jenderal Hortikultura. 2013. Volume ekspor impor total sayuran tahun 2012. http://hortikultura.deptan.go.id/index. [21 September 2013].

Hafsah, S., S. Sastrosumarjo, S. Sujiprihati, Sobir, S.H. Hidayat. 2007. Daya gabung dan heterosis ketahanan papaya (Carica papaya L.) terhadap penyakit antranoksa. Bul. Agron. 35(3):197-204.

Herison, C., Rustikawati, Sudarsono. 2001. Studi potensi pada persilangan beberapa galur cabai merah (Capsicum annuum L.). Bul. Agron. 29(1):23-26.

Iriany, R.N., S. Sujiprihati, M. Syukur, J. Koswara, M. Yunus. 2011. Evaluasi daya gabung dan heterosis lima galur jagung manis (Zea mays var. saccharata) hasil persilangan dialel. J. Agron. Indonesia. 39(2):103111.

Prajnanta, F. 2007. Agribisnis Cabai Hibrida. Penebar Swadaya. Jakarta.162 hlm.

Sitaresmi, T., S. Sujiprihati, M. Syukur. 2010. Combining ability of several introducedand local chili pepper (Capsicum annuum L.) genotypes and heterosis of the offsprings. J. Agron. Indonesia. 38(3): 212-217.

Sujiprihati, S., M. Syukur, R. Yunianti, Undang. 2007. Pendugaan nilai heterosis dan daya gabung beberapa komponene hasil pada persilangan dialel penuh enem genotipe cabai (Capsicum annuum L). Bul. Agron. 35(1): 28-35.

Syukur, M., S. Sujiprihati, R. Yunianti. 2015. Teknik Pemuliaan Tanaman. Edisi Revisi. Penebar Swadaya. Bogor.

Tembhurne, B.V., S.K. Rao. 2012. Heterosis and combining ability in CMS based hybrid chili (Capsicum annuum L.). Journal of Agricultural Science 4(10): 89-96. 